\title{
A Simple Method to Increase the Amount of Energy Produced by the Photovoltaic Panels
}

\author{
Daniel Tudor Cotfas and Petru Adrian Cotfas \\ Department of Electronics and Computers, Transilvania University of Brasov, 50036 Brasov, Romania \\ Correspondence should be addressed to Daniel Tudor Cotfas; dtcotfas@unitbv.ro
}

Received 31 May 2013; Accepted 4 November 2013; Published 19 January 2014

Academic Editor: David Lee Phillips

Copyright (C) 2014 D. T. Cotfas and P. A. Cotfas. This is an open access article distributed under the Creative Commons Attribution License, which permits unrestricted use, distribution, and reproduction in any medium, provided the original work is properly cited.

\begin{abstract}
The photovoltaic energy can become competitive by the conjugate effort of the researchers and manufacturers. Increasing the amount of electricity supplied by photovoltaic panels is a challenge. The paper briefly presents some methods which can lead to achieving this goal. A simple method to increase the quantity of the electrical energy delivered by the photovoltaic panels is also presented in this paper alongside the experimental setup and the software created in LabVIEW for monitoring the output of the panels.
\end{abstract}

\section{Introduction}

The importance of renewable energy as a major source of energy for the entire world gradually grew, alongside the conventional energy sources. Due to the development of some countries with large populations such as China, India, and Brazil the energy requirements grew exponentially.

The solutions for these requirements can be found in the exploitations of fossil fuels, leading to pollution increase and amplification of greenhouse effect and, as an alternative, there is the use of renewable energy and increasing its efficiency.

The development of the renewable energy domain of the last years can also be explained by the aid and involvement of the politics. Countries such as USA, Canada, China, India, and European Union had created the legal frame for support using the subsidies, feed-in-tariff, fiscal instruments, creating the trading of green certificates, and so forth $[1,2]$. Most of the countries have a declared goal for the renewable energy. California, state of USA, has an ambitious target$33 \%$ of the electricity must be produced from the renewable energy until $2020[2,3]$. The fixed target is that until 2020 in the European Union $20 \%$ of the total energy must be obtained from renewable energy [4]. The members of the European Union have different targets; for example, Romania must obtain $24 \%$ of the total energy from renewable sources $[2,4]$. Also, Japan has a high target for renewable energy production; this is $25 \%-35 \%$ from the total energy. China has 15\% until 2020 and Australia has at least $20 \%$ of the electricity $[2,5,6]$.

The photovoltaic energy becomes one of the most important types of renewable energy because the sun energy is free, there is an updated technology of using the silicon in electronics and this is easily transferrable to the manufacturing of solar cells, new types of solar cells and materials are being developed due to competiveness and the competition between researchers, and last, but not least, because of the political and economical factors, by the environmental rules imposed and by investment. Thus a favorable environment was created for the investments and the development of the research in the domain. In Romania there is a very simulating feed-in-tariffs program for the photovoltaic energy. The investors receive six green certificates for each MW produced. One certificate has a value up to 55 Euro.

The major investments are found in new photovoltaic energy plants positioned in open land which is not in general proper for agriculture, on the roofs of the houses, on large industrial or commercial building roofs which are flat, on the building's facade, and so forth [7].

To obtain the position it now has among the renewable energy sources, the photovoltaic energy had to gradually increase its efficiency and output and to offer optimum solutions for the integration in the environment where 
the photovoltaic panels are placed in order to avoid esthetic pollution [8]. This paper briefly presents the methods developed in order to make the photovoltaic energy competitive and also a simple method allowing the increase of photovoltaic panels output.

\section{Methods}

Research has led to the development of some possibilities to increase the quantity of electrical energy generated by the photovoltaic panels.

The first possibility is to use the photovoltaic cells with high efficiency to build photovoltaic panels, very suitable for space applications and others to ensure energy efficiency. The monocrystalline silicon solar cell, $\mathrm{mc}-\mathrm{Si}$, has been the most widely used to build the photovoltaic panels so far. The efficiency for the best mc-Si solar cell is $25 \%$ and the best photovoltaic panel made by monocrystalline silicon is $22.9 \%$ [9]. The mc-Si and the polycrystalline silicon photovoltaic panels, which have the best efficiency of $18.5 \%$, represent about $83 \%$ of the module market share $[7,10]$. The thin film GaAs photovoltaic panel has the efficiency of $24.1 \%$. The measurements to determine the photovoltaic panels' efficiency were made for standard test condition: $1000 \mathrm{~W} / \mathrm{m}^{2}$, $25^{\circ} \mathrm{C}$, and AM 1.5 [9].

The increase of the active area of photovoltaic panels is the second method to obtain more energy output. In the past, the shape of the solar cells used was circular, thus the active area of the photovoltaic module being much reduced. The using of mc-Si solar cells with cut-off corners (octagonal shape) led to the increase of the active area of the module. The square shape of the solar cells maximizes the active area of the moduletoday the dimensions of the solar cells are $15 \mathrm{~cm} \times 15 \mathrm{~cm}$. The free space between the solar cells was also reduced at its maximum [7].

The orientation of the photovoltaic panels is important for the increase of the energy delivered. If they are in a fixed position, then they must face South and the inclination must be at the optimum angle. There is software which facilitates the calculation of this angle [11].

Using the sun tracker systems, the photovoltaic panels follow the motion of the sun on the sky. The solar radiation comes directly on the module and the amount of supplied energy increases. There are many types of sun tracker systems. These can be with one single axis, with two equatorial or azimuth axes, using sensors or mathematical algorithm for positioning [12-14].

The solar cells have a limited spectral response function of the material type used for the cells. This problem can be solved by using multijunction solar cells, which use the large spectrum and the efficiency of the multijunction cells reaches $37.7 \%$ for InGaP/GaAs/InGaAs [9]. These types of solar cells are generally used in solar concentrator systems. The area of multijunction solar cells used in concentrator systems of solar radiation is small, thus obtaining high efficiency and energy amounts, at 942 suns the efficiency being 44\% [9]. The amount of materials used is reduced by shrinking the area of the cells. A concentrating system of the solar radiation is

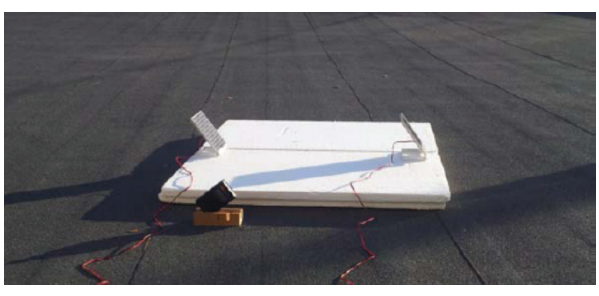

(a)

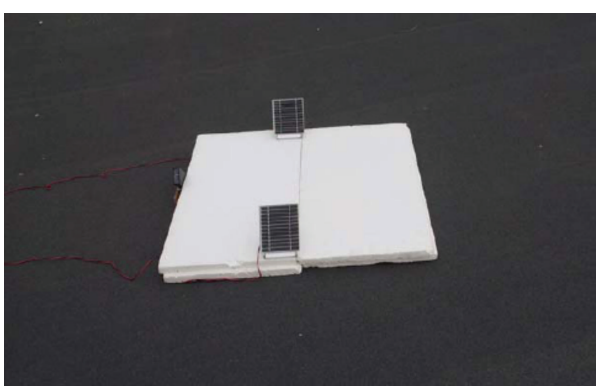

(b)

FIGURE 1: The photovoltaic panels positioning. (a) On a clear day; (b) on a cloudy day.

required, but the price of optic materials used (mirrors and lenses) is lower than the necessary price to obtain the same amount of energy using photovoltaic panels [15].

\section{Experiment Setup}

This paper proposes a simple method to increase the quantity of energy generated by the photovoltaic panels mounted on the large flat roof, as in Figure 1.

The flat roofs of the blocks and commercial or industrial spaces are generally covered with waterproof materials of a grey-black color.

Using these waterproof materials gives a small reflection of the solar radiation, implying a high absorption. The result is heating of the roofs and this implicitly leads to raising the temperature in rooms with such ceilings. This leads to air conditioning of the rooms, thus the costs implied by the electricity consumption rising.

If for water insulation white materials are used, presenting a high reflection of solar radiation, the effect of ceiling heating considerably reduces, and this surface becomes a solar concentrator.

In order to determine the amount of output energy rise in case of photovoltaic panels, the following experimental setup was realized.

(i) Two identical panels in terms of manufacturer, area, and type of solar cells used are disposed such that the active part of the first faces the dark grey surface and that of the other faces the white one (expanded polystyrene) (Figure 1). The distance between the panels is calculated so that it is not shadowed. Both photovoltaic panels were inclined at an optimum angle for Brasov, of $35^{\circ}$ [11]. The photovoltaic panels were previously measured, under the same testing 


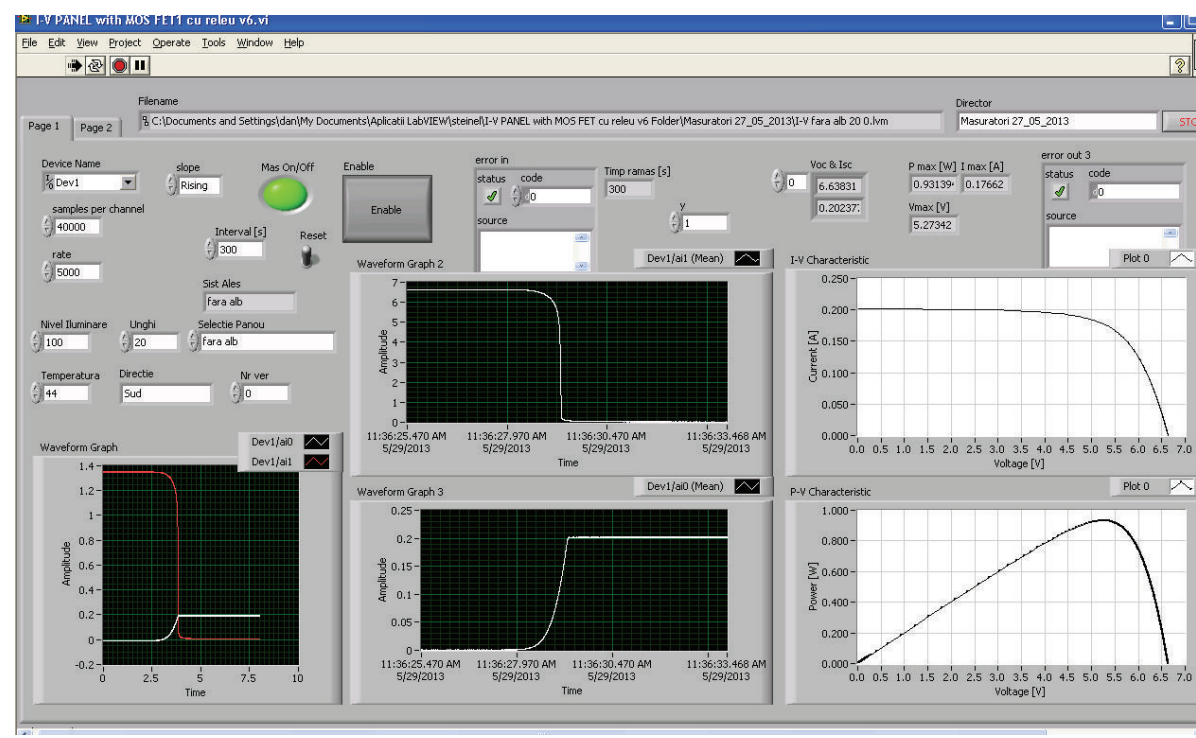

Figure 2: The application to measure the $I-V$ and $P-V$ characteristics of photovoltaic panels.

conditions, to make the necessary corrections so that the differences of output are caused only by the testing surface. The photovoltaic panels are built from monocrystalline silicon cells, with the dimensions of $13 \mathrm{~cm} \times 17 \mathrm{~cm}$.

(ii) The measurement of the solar radiation was made using a pyranometer positioned at the same inclination angle as the photovoltaic panels. The pyranometer was used for the study of the gain function of the irradiance, its accuracy being $1 \mathrm{~W} / \mathrm{m}^{2}$.

(iii) For the acquisition and control of the measurement system an NI 6036 acquisition board was used.

(iv) The output monitoring for the photovoltaic panels was realized by measuring the $I-V$ characteristic. This is a widely used tool, as it permits the determination of all important parameters of the solar cells and panels. The measurement system created by the authors permits the quasi simultaneous rise of the two $I-V$ characteristics for the two photovoltaic panels, the interval between two measurements being $1 \mathrm{~s}$. The rise of the characteristic is realized using a capacitor as a variable load during charging.

(v) The control and monitoring software was created in the graphical language program LabVIEW. The application panel of monitoring is presented in Figure 2.

(vi) The measurement of temperature on the back of photovoltaic panels was made using thermocouples and two Agilent multimeters.

\section{Results and Discussion}

The monitoring of the photovoltaic panels and the energy gain was realized for several days. Clear days were chosen as well as cloudy or days with variable conditions.
TABLE 1: Measured values of albedo.

\begin{tabular}{lc}
\hline Surface types & Measured values of albedo \\
\hline Bituminous membrane & 0.131 \\
White expanded polystyrene & 0.83 \\
Old snow & 0.45 \\
Fresh snow & 0.92 \\
Thick green grass & 0.23 \\
Rare green grass & 0.204 \\
Dry soil (dark) & 0.09 \\
\hline
\end{tabular}

The albedo method was used to determine the radiation reflected by different surfaces-the ratio between the radiation reflected by the surface under study and the global radiation. In Table 1 some albedo values are presented for different types of material surface [16].

The ratio between the radiation reflected by the two surfaces used in the experiment, white expanded polystyrene (WEP) and bituminous membrane (BP), shows that the WEP reflects by 6.34 times more radiation than $\mathrm{BP}$. This shows that the white surfaces can be used to raise the quantity of energy generated by the photovoltaic panels, without supplementary costs. The experiment described above was realized starting from this observation.

For the comparison, the maximum power $\left(P_{m}\right)$ generated by the two panels used for measurements was taken into consideration.

The software created permits the determination of other important parameters: $I_{\mathrm{sc}}$, short circuit current; $V_{\mathrm{oc}}$, open circuit voltage; $I_{\max }$, current at $P_{\max } ; V_{\max }$, voltage at $P_{\max }$ (Figure 2). The saving of the data permits their ulterior processing. The measurement interval can be varied function of the requirements.

The $I-V$ and $P-V$ characteristics of the two photovoltaic panels at $990 \mathrm{~W} / \mathrm{m}^{2}$ irradiance measured in May, when 


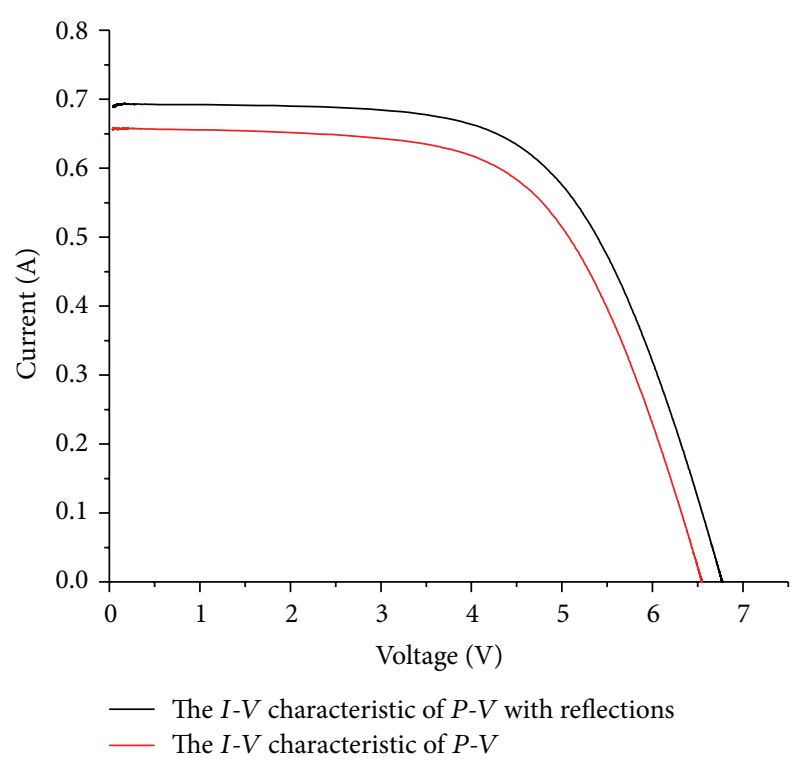

(a)

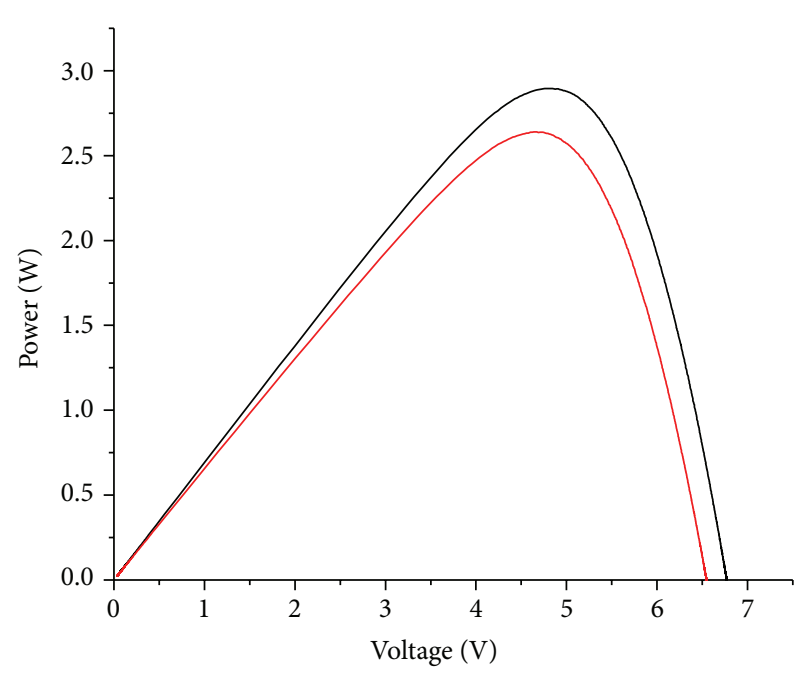

- The $I-V$ characteristic of $P-V$ with reflections - The $I-V$ characteristic of $P-V$

(b)

FIgURE 3: The $I-V$ (a) and $P-V$ (b) characteristics for two photovoltaic panels at the $990 \mathrm{~W} / \mathrm{m}^{2}$ irradiance.

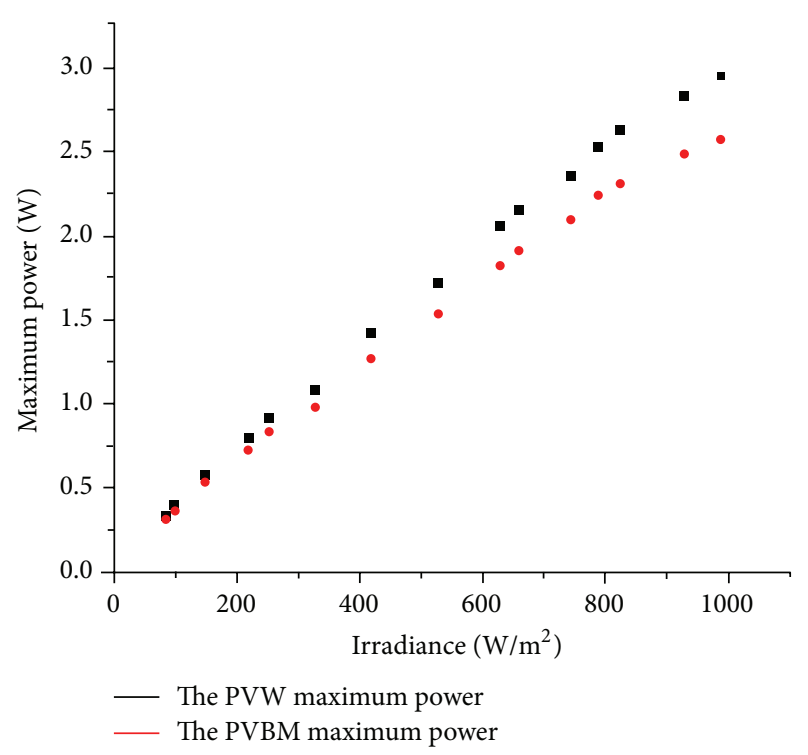

Figure 4: The maximum power versus irradiance for the two photovoltaic panels.

the optimum inclination angle is $16^{\circ}$, are presented in Figure 3 . The photovoltaic panel with the active area oriented towards the white surface (PVW) generates $P_{m}=2.94 \mathrm{~W}$ and the photovoltaic panel with the active area oriented towards the bituminous membrane surface (PVBM) generates $P_{m}=$ $2.56 \mathrm{~W}$. In this case the percentage gain is $14.84 \%$.

The temperature at the back of the PVW $\left(43^{\circ} \mathrm{C}\right)$ is higher than that at the back of the PVBM $\left(38^{\circ} \mathrm{C}\right)$ for the irradiance $990 \mathrm{~W} / \mathrm{m}^{2}$ with $4^{\circ} \mathrm{C}$. This difference becomes smaller for reduced illumination levels, under $0.5^{\circ} \mathrm{C}$ for $100 \mathrm{~W} / \mathrm{m}^{2}$. The maximum power decreases with $0.66 \%$ per ${ }^{\circ} \mathrm{C}$ for

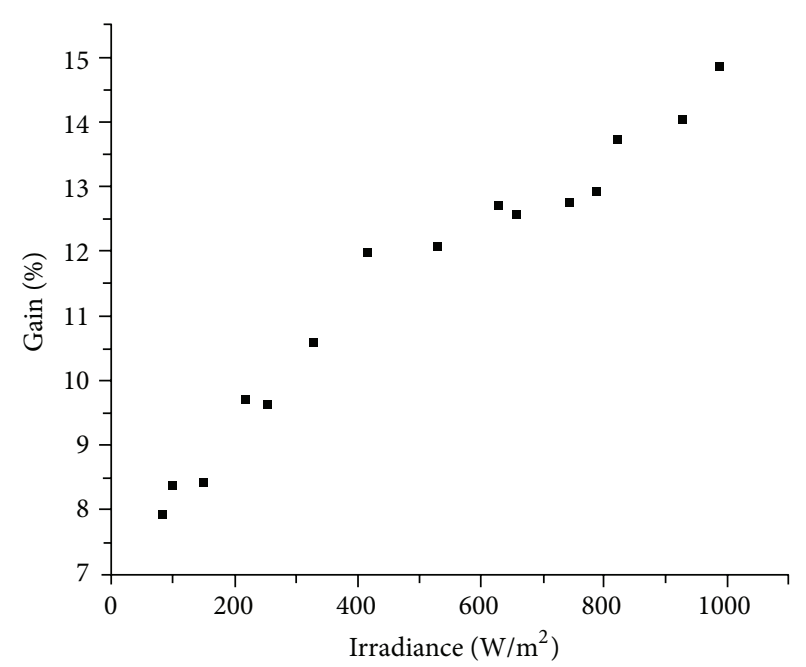

FIGURE 5: The percentage gain of PVW compared to PVBM function of the irradiance.

a monocrystalline silicon photovoltaic module [17]. The losses caused by the temperature rise are much smaller than the gain obtained by the radiation concentration, due to reflections on the white surface.

The maximum power gain of PVW in comparison to PVBM function of the irradiance is presented in Figure 4. A rise of gain is observed with the increase of the illumination level. The gain at $100 \mathrm{~W} / \mathrm{m}^{2}$ is $24 \mathrm{~mW}$, and at $1000 \mathrm{~W} / \mathrm{m}^{2}$ this can reach $380 \mathrm{~mW}$.

The dependence of the gain function on the irradiance in percentage was determined in order to see how much the gain represents from the maximum power generated (Figure 5). There can be noticed almost a double growth of the gain 
in percentage for 1 sun in comparison with the gain for $100 \mathrm{~W} / \mathrm{m}^{2}$.

For a clear day PSH - average peak solar hour-in Brasov in May is 5.2 hours. Considering the PSH value above, the total energy generated by the photovoltaic panel PVBM is of 13.31 Wh. The total energy gain for such a day is $2 \mathrm{Wh}$ with PVW.

For the cloudy days when the mean value of the irradiance is $150 \mathrm{~W} / \mathrm{m}^{2}$ the gain is smaller, in percents, being $8.5 \%$.

As the optimum angle modifies during the year (for Brasov from $12^{\circ}$ in June to $64^{\circ}$ in January) the gain rises as we distance from the smallest value of the optimum inclination angle.

A solution that can be identified from this study for the photovoltaic systems, for which the main aim is not necessarily the maximizing of annual energy quantity, but more precisely the maximizing in critical periods, is the positioning of the systems at an optimum inclination angle for those periods and using the reflections caused by snow and/or white surfaces created. It can be seen from Table 1 that the albedo for the snow decreases from $92 \%$ for the freshly deposited snow until $45 \%$ for old snow. The gain thus obtained can overcome the gain obtained in this study.

In case on the surface of the flat roof the number of the solar panels is maximized, the reflection area will be lowered. The maximizing of the panels number is done keeping into account the shadowing effect. By using white waterproof materials, and considering the obtained gain, the distance between the panels can be raised so that the panels shadowing period is minimized. Therefore, not only a higher quantity of electrical energy is generated by the photovoltaic system, but also the lifetime of the panels is extended.

In case of solar farms placed on open areas, the green grass layer leads to an increase in the quantity of electrical energy generated. The ratio between the solar radiations reflected by the two surfaces, green grass (GG) and dry soil (DS), shows that the GG reflects by 2.56 times more radiation than DS; see Table 1. Another beneficial effect of the grass carpet is maintaining a low temperature at the ground level and creating the air currents cooling the panels.

\section{Conclusions}

The method presented in the paper leads to a gain in energy generated without supplementary costs and materials and at the same time to energy saving on months with abundant sunshine, energy that should have been used for air conditioning.

Using white waterproof materials for flat roofs raises the amount of electrical energy generated by the photovoltaic panels with values between $7 \%$ and $15 \%$, in case of the study realized, for monocrystalline photovoltaic panels.

The temperature difference between the photovoltaic panel PVW and PVBM is low; thus the reducing of the energy gain generated by PVW because of this is smaller.

Another beneficial effect of white surfaces is the possibility of maximizing the time of panel shadowing thus creating the premises for the prolonging of their lifetime.
Another idea that can be given by this study is using reflections due to snow especially for photovoltaic systems with critical periods in November-February.

The maintenance of the grass layer of open fields also leads to an increase of the energy quantity generated.

The future research will be dedicated to the effect upon the energy quantity generated by the photovoltaic panels due to the color changes of the waterproof material in time. The energy gain function of the optimum monthly tilt angle will be studied.

\section{Conflict of Interests}

The authors declare that there is no conflict of interests regarding the publication of this paper.

\section{Acknowledgment}

The authors would like to express their appreciation to Steinel Company for equipment offered.

\section{References}

[1] R. Haas, C. Panzer, G. Resch, M. Ragwitz, G. Reece, and A. Held, "A historical review of promotion strategies for electricity from renewable energy sources in EU countries," Renewable and Sustainable Energy Reviews, vol. 15, no. 2, pp. 1003-1034, 2011.

[2] S. E. Colesca and C. N. Ciocoiu, "An overview of the Romanian renewable energy sector," Renewable and Sustainable Energy Reviews, vol. 24, pp. 149-158, 2013.

[3] S. Carley, "State renewable energy electricity policies: an empirical evaluation of effectiveness," Energy Policy, vol. 37, no. 8, pp. 3071-3081, 2009

[4] European Commission (EC), "Directive2009/28/EC of the European Parliament and Council on the promotion of the use ofenergy from renewable sources," 2009.

[5] E. Martinot, "Renewable power for China: past, present, and future," Frontiers of Energy and Power Engineering in China, vol. 4, no. 3, pp. 287-294, 2010.

[6] Commonwealth of Australia, Renewable Energy Target Review, Commonwealth of Australia, Canberra, Australia, 2012.

[7] E. Kaplani, "Detection of degradation effects in field-aged mc-Si solar cells through IR thermography and digital image processing," International Journal of Photoenergy, vol. 2012, Article ID 396792, 11 pages, 2012.

[8] H. Águas, S. K. Ram, A. Araújo et al., "Silicon thin film solar cells on commercial tiles," Energy and Environmental Science, vol. 4, no. 11, pp. 4620-4632, 2011.

[9] M. A. Green, K. Emery, Y. Hishikawa, W. Warta, and E. D. Dunlop, "Solar cell efficiency tables (version 41)," Progress in Photovoltaics, vol. 21, pp. 1-11, 2013.

[10] A. Goetzberger, C. Hebling, and H. Schock, "Photovoltaic materials, history, status and outlook," Materials Science and Engineering R, vol. 40, no. 1, pp. 1-46, 2003.

[11] Photovoltaic Geographical Information System, http://re.jrc.ec .europa.eu/pvgis/apps4/pvest.php.

[12] D. Cotfas, P. Cotfas, S. Kaplanis, D. Ursutiu, and C. Samoila, "Sun tracker system vs fixed system," Bulletin of the Transilvania University of Brasov, vol. 1, no. 50, pp. 545-552, 2008. 
[13] M. Serhan and L. El-Chaar, "Two axes sun tracking system: comparsion with a fixed system," in Proceedings of the International Conference on Renewable Energies and Power Quality (ICREPQ '10), Granada, Spain, March, 2010.

[14] H. Mousazadeh, A. Keyhani, A. Javadi, H. Mobli, K. Abrinia, and A. Sharifi, "A review of principle and sun-tracking methods for maximizing solar systems output," Renewable and Sustainable Energy Reviews, vol. 13, no. 8, pp. 1800-1818, 2009.

[15] P. Pérez-Higueras, E. Muñoz, G. Almonacid, and P. G. Vidal, "High concentrator photoVoltaics efficiencies: present status and forecast," Renewable and Sustainable Energy Reviews, vol. 15, no. 4, pp. 1810-1815, 2011.

[16] D. T. Cotfas, S. Kaplanis, P. A. Cotfas, D. Ursutiu, and C. Samoila, "A new albedometer based on solar cells," in Proceedings of the World Renewable Energy Congress X, A. Sayigh, Ed., Glasgow, UK, July 2008.

[17] E. Radziemska, "The effect of temperature on the power drop in crystalline silicon solar cells," Renewable Energy, vol. 28, no. 1, pp. 1-12, 2003. 

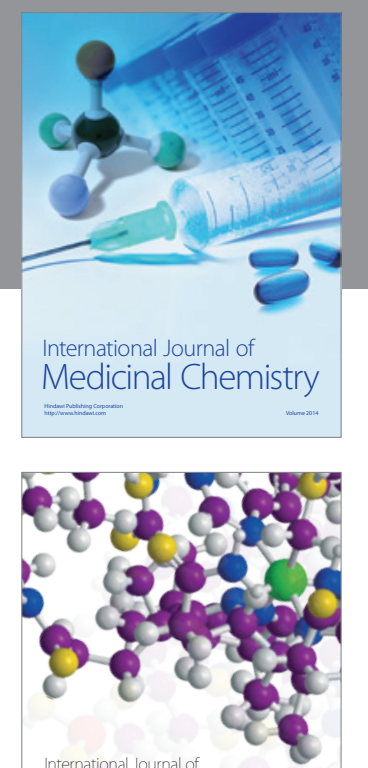

\section{Carbohydrate} Chemistry

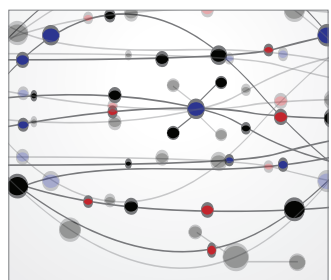

The Scientific World Journal
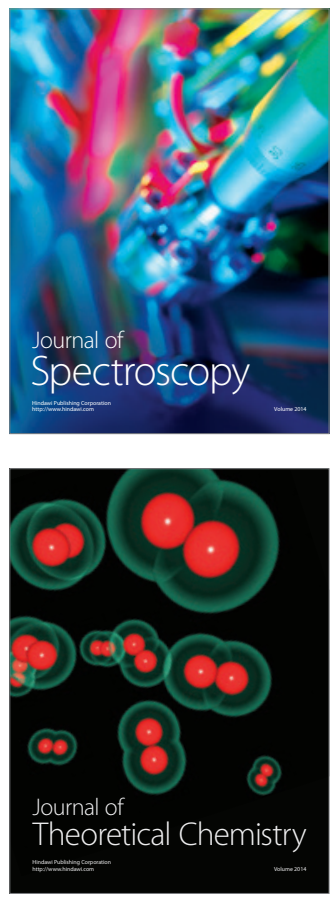
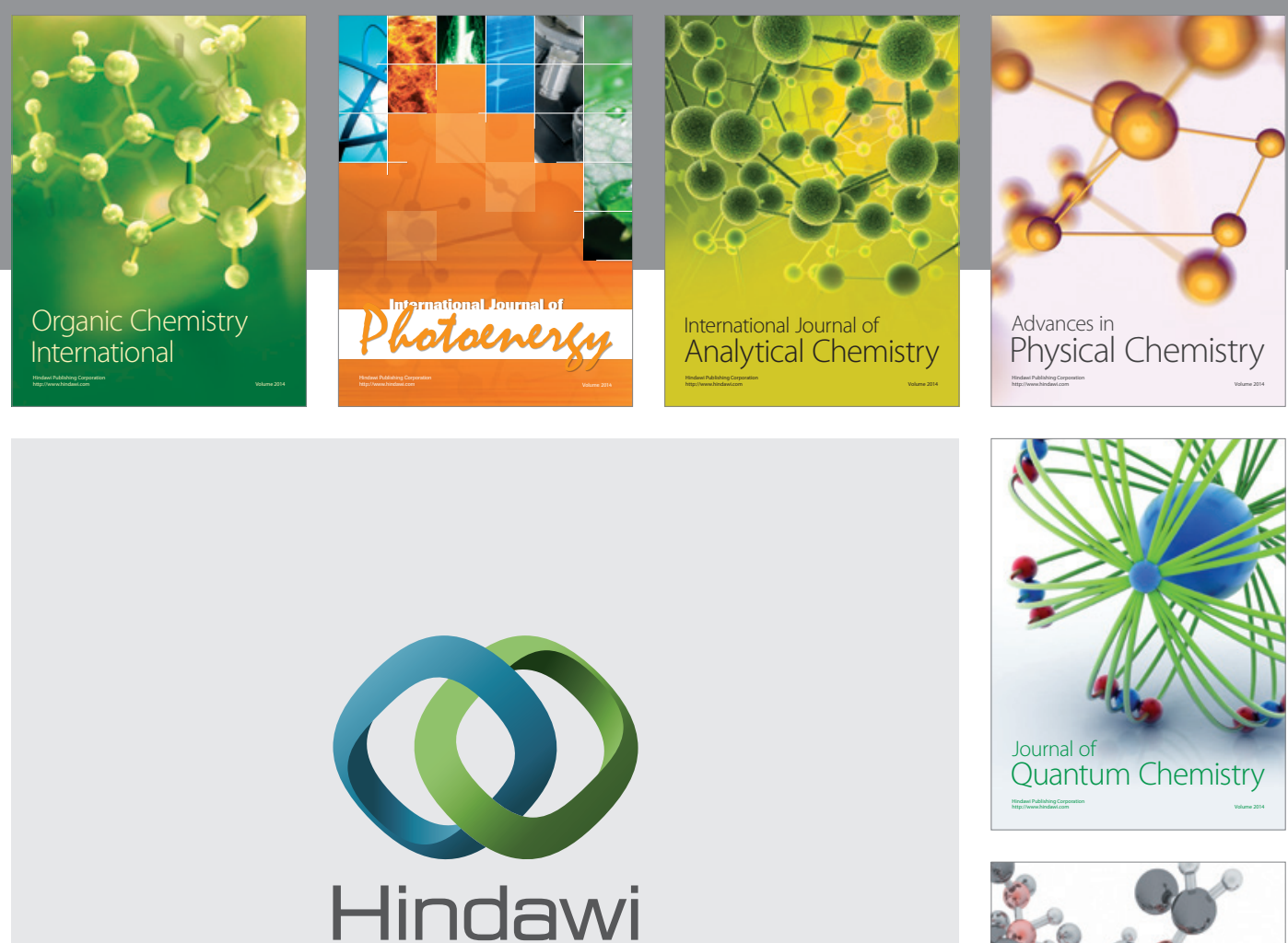

Submit your manuscripts at

http://www.hindawi.com

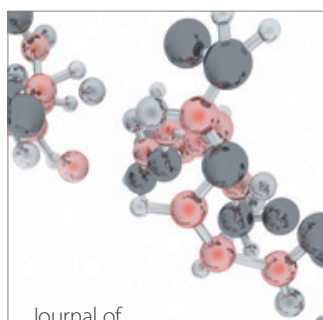

Analytical Methods

in Chemistry

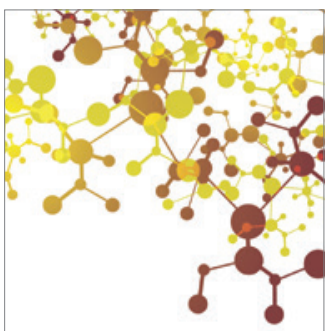

Journal of

Applied Chemistry

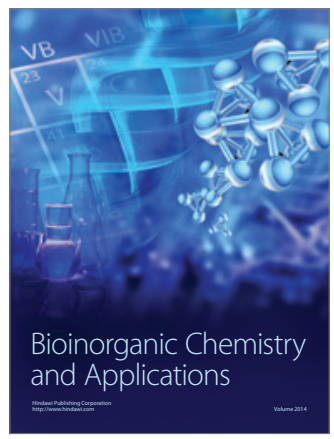

Inorganic Chemistry
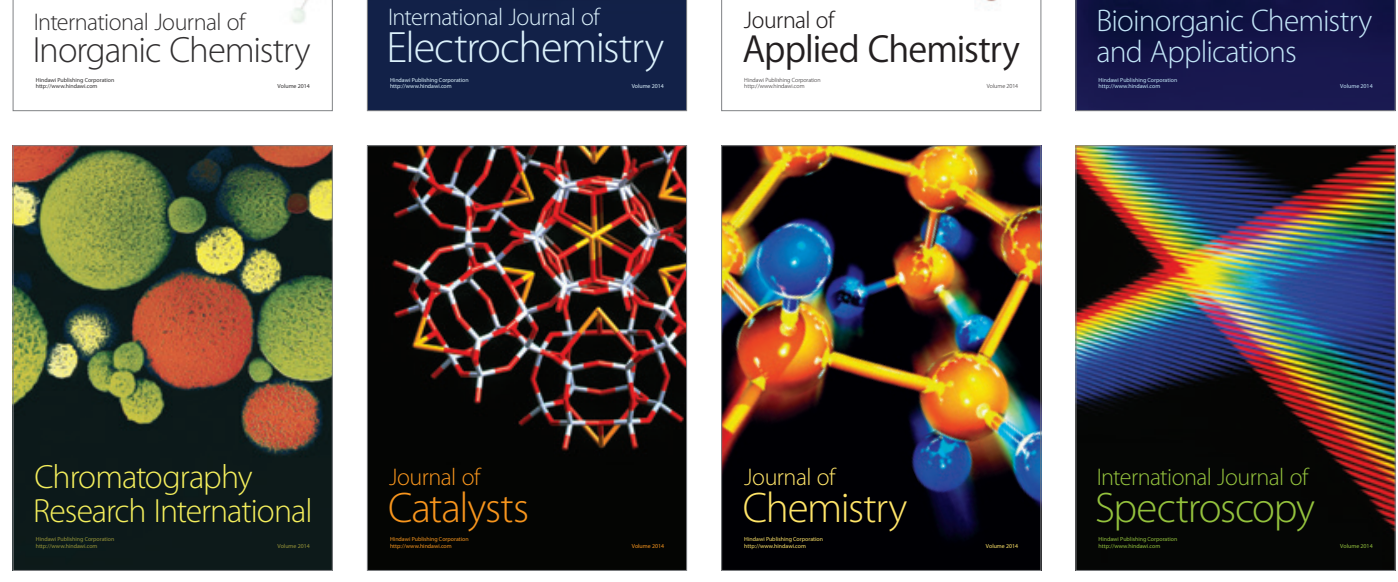